\title{
Switchgrass and Little Bluestem Cultivars Show Performance Variation Across Eight States in National Grass Trials
}

\author{
Mary H. Meyer ${ }^{1,10}$, Pamela J. Bennett ${ }^{2}$, Barbara Fair ${ }^{3}$, \\ James E. Klett ${ }^{4}$, Kimberly Moore ${ }^{5}$, H. Brent Pemberton ${ }^{6}$, \\ Leonard Perry ${ }^{7}$, Jane Rozum ${ }^{4}$, Alan Shay ${ }^{8}$, and Matthew D. Taylor ${ }^{9}$
}

\begin{abstract}
AdDitional INDEX wORDs. ornamental grasses, native grasses, landscape grasses, Panicum virgatum, Schizachyrium scoparium

Summary. Landscape plant evaluations were conducted in eight states: Colorado, Minnesota, North Carolina, Ohio, Oregon, Pennsylvania, Texas, and Vermont for 17 switchgrass (Panicum virgatum) and five little bluestem (Schizachyrium scoparium) cultivars. Additional locations in Florida (Fort Lauderdale, Fort Pierce, Quincy, and Wimauma), Nebraska (Lincoln), and Lubbock and San Marcos completed 1 or 2 years of the trials. Plants were established in 2012 and data were collected for 3 years, 2013-15. Sites were asked to compile annual data on plant height, width, flowering time, fall color, pests, foliage color determined by the Royal Horticultural Society's color chart, plant form, flowering date, floral impact, self-seeding, winter injury, landscape impact, and mortality. Texas A\&M Agricultural Research and Extension Center (Overton), Florida (all four locations), and Vermont had the highest mortality rate. Southern Florida locations lost $\mathbf{5 0 \%}$ of their plants by the end of 2014. Wide variation was reported for landscape impact, individual cultivar height, and width from different regions of the United States. Three of the 17 switchgrass cultivars, Cloud 9, Northwind, and Thundercloud, had a rating of 4.0 or higher averaged over six or more locations for plant form, floral, and landscape impact. 'Shenandoah' and 'Warrior' switchgrass had a rating of 4.0 or higher averaged over six or more locations for plant form and landscape impact, but not floral impact. Only one of the five little bluestem cultivars, Blue Heaven ${ }^{\circledR}$ rated 4.0 or higher, for plant form and landscape impact when averaged over six or more locations. This range of variability in landscape plant performance demonstrates the importance of local plant evaluations.
\end{abstract}

$\mathrm{N}$ ative herbaceous perennials, especially grasses, have increased in popularity in

We thank Bluemel Nursery (Baldwin, MD), Emerald Coast (Pensacola, FL), Hoffman Nursery (Rougemont, $\mathrm{NC}$ ), and Walters Gardens (Zeeland, MI) for donating materials and Andrew Petran for statistical analysis.

${ }^{1}$ Department of Horticultural Science, University of Minnesota, 1970 Folwell Avenue, St Paul, MN 55108

${ }^{2}$ Ohio State University Extension Clark County, 3130 East Main Street, Springfield, OH 45505

${ }^{3}$ Department of Horticultural Science, North Carolina State University, 4415 Beryl Road, Raleigh, NC 37606

${ }^{4}$ Department of Horticulture and L. Arch., Colorado State University, Campus Delivery 1173, Fort Collins, CO 80523

${ }^{5}$ Department of Environmental Horticulture, University of Florida, 3205 College Avenue, Davie, FL 33314

${ }^{6}$ Department of Horticultural Sciences, Texas A\&M Agricultural Research and Extension Center, P.O. Box 200, Overton, TX 75684

${ }^{7}$ Department of Plant and Soil Science, University of Vermont, 568 Westford Road, Milton, VT 05468

${ }^{8}$ Department of Horticulture, Oregon State University, 4143 Ag Life Sciences Building, Corvallis, OR 97331

${ }^{9}$ Horticulture Research, Longwood Gardens, 409 Conservatory Road, Kennett Square, PA 19348

${ }^{10}$ Corresponding author. E-mail: meyer023@umn.edu doi: 10.21273/HORTTECH03795-17 recent years due to their low maintenance requirements, ecosystem services, and pollinator benefits (Meyer, 2012; USDA, 2014). Most native grass cultivars have been selected from wild populations, where literally, they stood out in a field or along a roadside. A few are the result of human intervention with natural out-crossing when several cultivars are deliberately grown together or progeny selected from careful hand pollination (Table 1 ). In all cases, these cultivars are coming from a wide range of geographic areas and backgrounds. Most are clonally propagated, occasionally patented, and are marketed as superior forms for widespread landscape use across the United States (Table 1).

Both switchgrass and little bluestem have large native ranges, encompassing most of the United States (USDA, 2017). Adapted to a wide range of climates, with documented morphological variability (McMillan, 1964) it is difficult to predict the landscape performance of cultivars of these species when grown across the United States. Multistate herbaceous perennial trials are not common, especially for multiple years across diverse climatic regions of the United States. A new initiative with the Perennial Plant Association (Hilliard, $\mathrm{OH}$ ) and AllAmerica Selections (Downers Grove, IL) is expected to fill this void in the future (Blazek, 2017b). Herbaceous annual flower and vegetable trials have been conducted for many years by the All-America Selections organization (Blazek, 2017a) and universities within specific states: Colorado State University, Fort Collins (Klett, 2017); Michigan State University, East Lansing (2017); Ohio State University, Columbus (Bennett, 2017); Pennsylvania State University, College Park (Adam, 2017); Texas A\&M Agricultural Research and Extension Center, Overton (Pemberton, 2017); and the University of Georgia, Athens (Ruter, 2017). Botanic gardens also conduct trials and publish results for their local area Chicago Botanic Garden, Glencoe, IL (Hawke, 2013; 2017); Dallas Arboretum, Austin, TX (Decker, 2017); and Longwood Gardens, Kennett Square, PA (Taylor, 2017). Because of the diverse origin of grasses in the trade, their wide variability in form and size, and the challenge for retailers to carry multiple cultivars, we conducted an evaluation of 17 cultivars of switchgrass and five cultivars of little bluestem (Table 1 ) in eight states (Table 2) from 2012 to 2015 to determine which cultivars would perform consistently above average for plant form, landscape, and floral impact across states and regions.

\section{Methods and materials}

Evaluation locations self-selected to participate in these trials by responding to an e-mail sent to several

\begin{tabular}{llll}
\hline $\begin{array}{l}\text { Units } \\
\begin{array}{l}\text { To convert U.S. to SI, } \\
\text { multiply by }\end{array}\end{array}$ & U.S. unit & SI unit & $\begin{array}{l}\text { To convert SI to U.S., } \\
\text { multiply by }\end{array}$ \\
\hline 0.3048 & $\mathrm{ft}$ & $\mathrm{m}$ & 3.2808 \\
2.54 & inch $(\mathrm{es})$ & $\mathrm{cm}$ & 0.3937
\end{tabular}


Table 1. Supplier, origin, year of introduction, plant patent, and references for five little bluestem and 17 switchgrass cultivars in national grass trials in 2012-15.

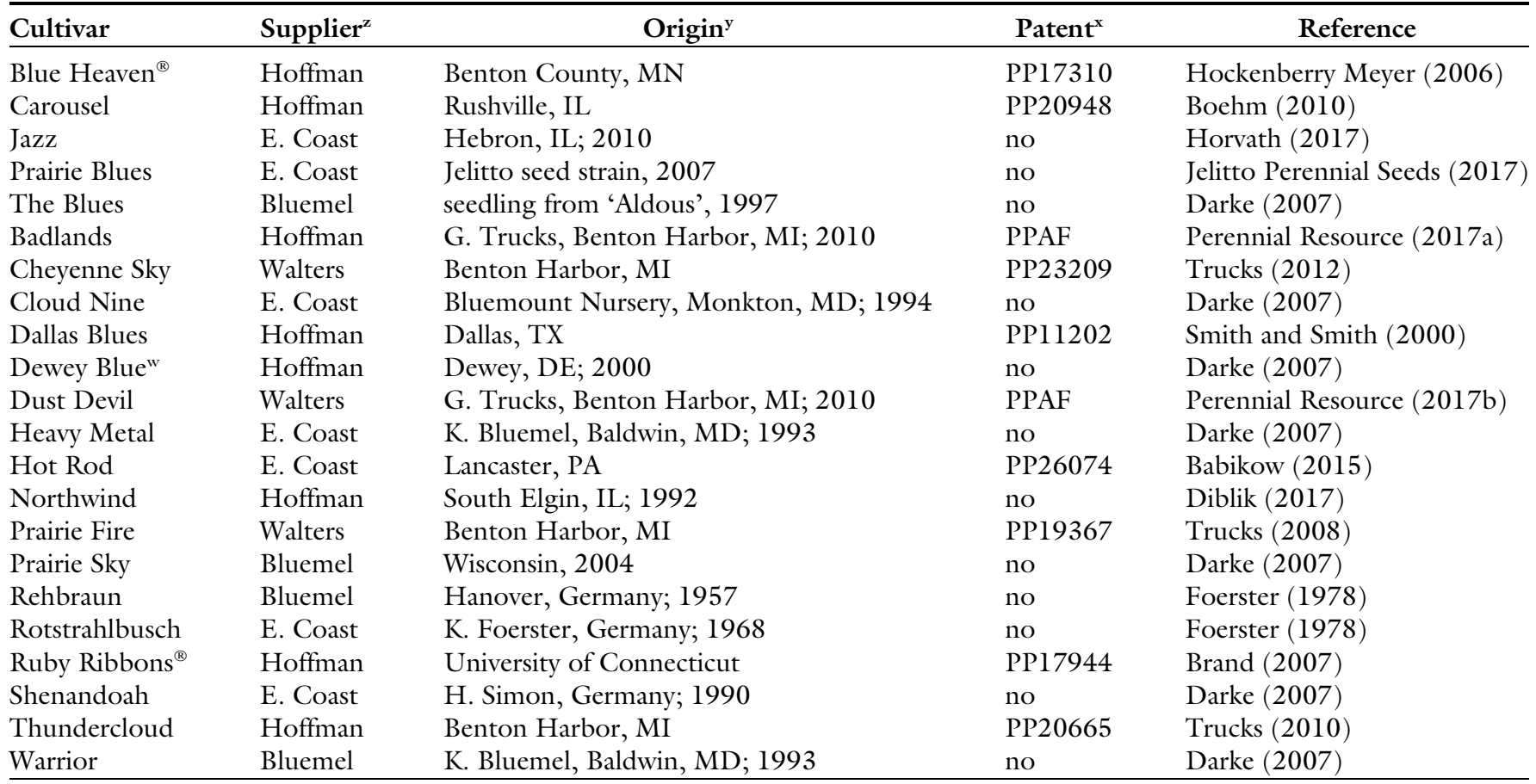

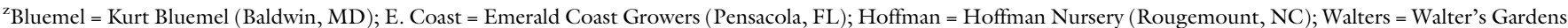
(Zeeland, MI).

${ }^{y}$ Location and date of introduction if different from reference. Jellitto = Jelitto Perennial Seeds (Louisville, KY).

${ }^{x} \mathrm{PP}=$ plant patent, $\mathrm{PPAF}=$ plant patent applied for (U.S. Patent and Trademark Office, 2017).

${ }^{\mathrm{w}}$ Bitter beachgrass.

Table 2. Collaborators and trial location information for national grass trials in 2012-15.

\begin{tabular}{|c|c|c|c|c|c|}
\hline State & Institution & Location & $\begin{array}{l}\text { USDA hardiness } \\
\text { zone }\end{array}$ & Latitude $\left({ }^{\circ} \mathbf{N}\right)$ & $\begin{array}{c}\text { Annual precipitation } \\
{\text { (inches) })^{\mathrm{z}}}\end{array}$ \\
\hline Colorado & Colorado State University & Fort Collins & $5 b$ & 45 & 16 \\
\hline Minnesota & University of Minnesota & Chaska & $4 b$ & 45 & 30 \\
\hline North Carolina & North Carolina State University & Raleigh & $7 \mathrm{~b}$ & 36 & 47 \\
\hline Ohio & Ohio State University & Springfield & $6 a$ & 40 & 39 \\
\hline Oregon & Oregon State University & Corvallis & $8 \mathrm{~b}$ & 44 & 48 \\
\hline Vermont & University of Vermont & Milton & $5 \mathrm{a}$ & 45 & 37 \\
\hline
\end{tabular}

${ }^{\mathrm{z}} 1$ inch $=2.54 \mathrm{~cm}$

American Society of Horticultural Science working group listserves in 2011. Participants signed an agreement that they would plant, maintain, and collect data over the 4 years of the trials. Participants were self-funded and received no compensation for their work. Most locations were already participating in some type of plant trial program and added these grasses to their field sites. All locations were given specific, identical directions (Meyer, 2017) for data collection, with each criteria defined (Table 3 ). Pemberton and Roberson (2001) developed the landscape impact rating scale that was shared with all collaborators and used throughout the trials (Table 3 ).

We selected as many cultivars of switchgrass and little bluestem as were available in the trade and could be obtained in sufficient supply in 2012. In Spring and early Summer 2012, plants were donated as plugs and mailed to trial participants from four growers (Table 1). Wholesale suppliers were used to assure that everyone received the same cultivar to evaluate and that all initial plants were uniform in size. Although larger plants would have assured faster establishment, availability and mailing costs dictated using plugs. Each location planted four plants of each cultivar for a total of 88 plants per location. Four plants per cultivar were recognized as a minimum number for trials, but priority was given to comparing a larger number of cultivars rather than high replication of a few cultivars. Plants were spaced 3-5 ft apart, in open, full sun, field conditions and watered and weeded as necessary to assure establishment. After establishment (from 2 to 6 weeks), supplemental water and weeding were minimal and used only where necessary to keep the plants from dying. Annual weeding 


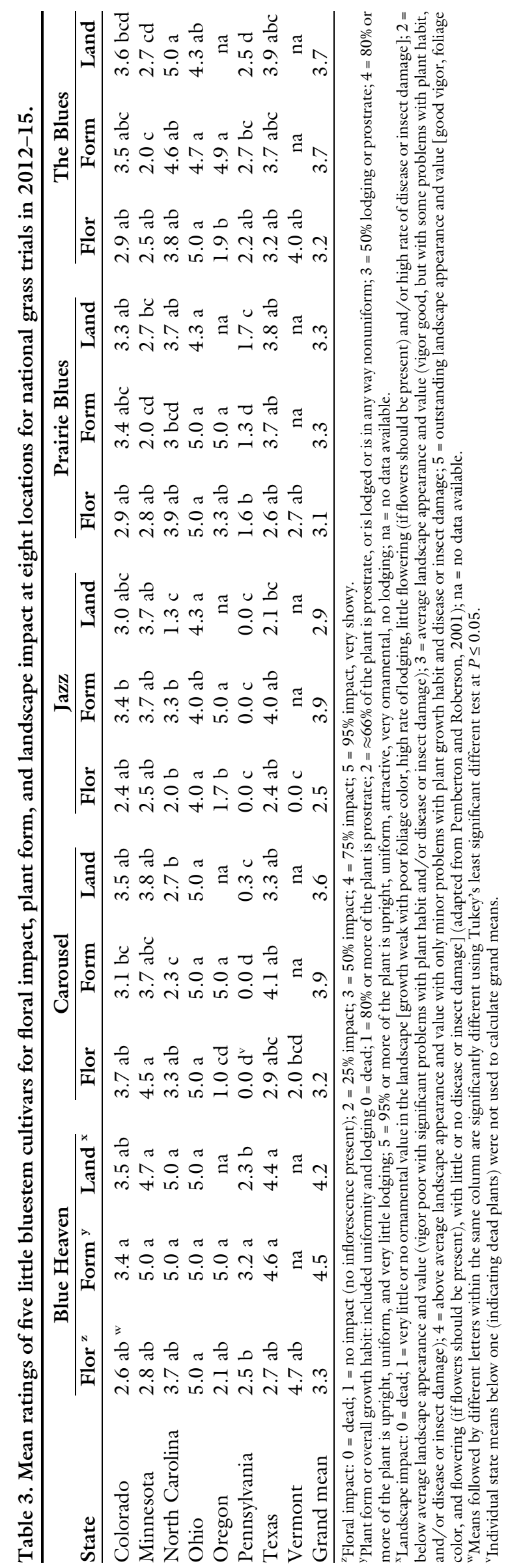

and mulching were conducted at all locations to minimize weed competition. In late winter or early spring, all plants were cut back to ground level to remove the previous year's growth. No supplemental fertilizer or pesticides were applied. The initial year, 2012, was considered the establishment year and only survival data were collected that first year. Data collection began in 2013. Trial locations were asked to begin measuring the following 13 traits in 2013: plant height and width [measured at maturity each year with measurements taken according to the definitions provided (Meyer, 2017)], flowering time, fall color, pest damage, foliage color (measured in midsummer) as determined by Royal Horticultural Society's color chart (RHS, 2007), plant form (recorded at plant maturity each year), flowering date, floral impact (recorded at time of peak flowering), self-seeding (measured by visible seedlings surrounding the plants), winter injury, landscape impact (recorded in the fall of each year when plants were at their mature annual size), and date of spring green-up. Specific criteria for taking these measurements and definitions for plant form, landscape, and floral impact can be found in Table 3 and online (Meyer, 2017).

In November of each year (2013-15), participants posted their results on the grass trials website (Meyer, 2017) usually in spreadsheet form. Cultivar results for 2013-15 for plant form, floral, and landscape impact were compared for significant differences among locations using $\mathrm{R}$ programming language (version 3.1.1; R Foundation for Statistical Computing, Vienna, Austria). Pairwise comparisons were conducted using Tukey's honest significant difference at $\alpha=0.05$. Plants that died were assigned a value of zero (no value) for the pairwise statistical analysis. Individual state means below a value of 1.0 (reflecting dead plants) were not used to calculate grand means for a specific cultivar.

\section{Results}

Eight locations maintained the trials over 4 years, 2012 for establishment and 2013-15, and collected annual data (Tables 3-5). Participants in Oregon, Texas, and Vermont replanted several cultivars 
with replacement plugs in 2012 or early 2013 because of transplant mortality. Not all locations had all four replications of each of the 22 cultivars over 4 years (Table 5 and Meyer, 2017). Although all collaborators agreed to the data to collect and were given the same directions, not all locations measured all 13 traits for the 3 years of data collection. Vermont participants did not measure plant form and only measured landscape impact in 2015. Oregon evaluators only measured landscape impact in 2015. Texas evaluators did not measure final height and width in 2015. All other locations measured survival including winter injury, plant form, landscape impact, floral impact height, and width for all cultivars for all 3 years (Tables 3-5 and Meyer, 2017).

Only 1 or 2 years of data were collected at the following locations: the University of Florida (Fort Lauderdale, Fort Pierce, Quincy, and Wimauma), the University of Nebraska (Lincoln), Texas State University (San Marcos), and Texas Tech University (Lubbock). Results were published for Florida (Ripak et al., 2014) and are not included in this article. Complete results by location and year can be found online (Meyer, 2017).

BEST PERFORMANCE FOR TWO OR MORE TRAITs. Three switchgrass cultivars: Cloud 9, Northwind, and Thundercloud rated 4.0 (5.0 scale) or higher from six or more locations for landscape impact, plant form, and floral impact. 'Shenandoah', 'Ruby Ribbons $^{\circledR}$, and 'Warrior' rated 4.0 or higher for above average means from six or more locations for plant form and landscape impact; however, only four locations had surviving 'Ruby Ribbons' ${ }^{\circledR}$ by 2015 (Table 4). Only 'Blue Heaven' ${ }^{\circledR}$ little bluestem was ranked 4.0 or higher for above average landscape impact and plant form at six or more locations (Table 3 ).

'Dewey Blue' bitter beachgrass (Panicum amarum) was rated the most consistent by collaborators with no significant difference at six or more locations for floral impact, plant form, or landscape impact with mean ratings of $3.8,3.3$, and 3.1 , respectively (Table 4).

Landscape Impact. Switchgrass cultivars Cloud 9, Northwind, Shenandoah, Thundercloud, and Warrior ranked 4.0 or higher for overall means from six locations for landscape impact (Table 4). 'Dallas Blues', 'Dust Devil', 'Heavy Metal', 'Rehbraun', and 'Rotstrahlbusch' had overall mean ratings of 3.5-3.9 for this trait. 'Hot Rod' (2.4) and 'Prairie Sky' (2.8) rated below 3.0 (average) for overall means from five and six locations, respectively, for landscape impact. 'Cheyenne Sky' (3.4) and 'Ruby Ribbons' ${ }^{\circledR}$ (4.0) had the most switchgrass mortality with only six locations reporting for these two cultivars by the end of the trial.

'Blue Heaven' ${ }^{\circledR}$ had the highest overall mean of the little bluestem cultivars for landscape impact at 4.2. 'The Blues' rated 3.7, and 'Jazz' (2.9) was evaluated as just below average performance for this trait (Table 3).

Plant form. Eleven switchgrass cultivars had mean ratings above average at 4.0 or higher for plant form: Badlands (4.1), Cloud Nine (4.3), Dallas Blues (4.1), Heavy Metal (4.3), Northwind (4.6), Rehbraun (4.2), Rotstrahlbusch (4.2), Ruby Ribbons $^{\circledR}$ (4.0), Shenandoah (4.6), Thundercloud (4.6), and Warrior (4.0) (Table 4). Lodging or falling over was measured as part of plant form and accounts for 'Prairie Sky's rating of $1.0(80 \%$ or more of the plant is prostrate), 1.6, and 1.8 in Minnesota, NC, and Pennsylvania, respectively. One location ranked 'Prairie Sky' as superior for plant form [Oregon (5.0)] and two rated it $80 \%$ upright [Colorado (4.2) and Ohio (4.3)]. 'Blue Heaven' ${ }^{\circledR}$ was the highest rated little bluestem for plant form (4.5). Other little bluestem were ranked very closely at 3.3-3.9 for plant form (Table 3).

Statistically, plant form ratings were the most consistent with 'Badlands', 'Cheyenne Sky', 'Dallas Blues', 'Dewey Blue' (bitter beachgrass), 'Dust Devil', 'Northwind', 'Rotstrahlbusch', 'Shenandoah', 'Thundercloud' switchgrass, and 'Blue Heaven' ${ }^{\circledR}$ little bluestem all showing above average means with no significant difference among locations (Tables 3 and 4 ).

Floral IMPaCT. Three switchgrass cultivars rated 4.0 or higher for floral impact across eight states: 'Cloud Nine' (4.1), 'Northwind' (4.1), and 'Thundercloud' (4.4). 'Cloud 9' and 'Thundercloud' have large panicles; 'Northwind' flowers are borne amidst the leaf blades. 'Dallas Blues', 'Dewey Blue' (bitter beachgrass), 'Heavy Metal', 'Rehbraun', 'Rotstrahlbusch', 'Shenandoah', and 'Warrior' had floral impact ratings of 3.6-3.8. 'Badlands', 'Hot Rod', and 'Ruby Ribbons ${ }^{\circledR}$ had ratings lower than 3.0 for floral impact.

Jazz little bluestem rated 2.5 for mean floral impact while the remaining four little bluestem cultivars were similar with 3.1-3.3 floral impact ratings.

Height and width. Cultivars varied greatly across the United States when measured for height and width (Table 5). 'Thundercloud' was the tallest and widest plant when averaged overall locations; while 'Hot Rod' was the shortest and narrowest (Table 5). 'Carousel' and 'Jazz' little bluestem were more than $30 \mathrm{~cm}$ shorter than the other three little bluestem cultivars. Averaging height and width over the eight locations may mask the actual height one could expect for their region or state; therefore, the average height and width measurements by trial location are listed in Table 5, along with the number of plants surviving at each location. 'Prairie Blues' little bluestem is seed propagated and this could account for this plant's variability and low performance. While genetic diversity can be an asset, in landscape performance, not knowing how a plant will perform can be a liability.

Within a specific cultivar, the largest plants were not necessarily found in the warmest states with the longest growing season. For example, plants grown at Longwood Gardens, near Philadelphia, PA, had the tallest measurements for seven switchgrass ('Badlands', 'Dallas Blues', 'Dust Devil', 'Northwind', 'Prairie Fire', 'Shenandoah', and 'Warrior') and one little bluestem ('Prairie Blues'). Texas participants reported four of the shortest switchgrass size measurements for 'Hot Rod', 'Prairie Sky', 'Rotstrahlbusch', and 'Shenandoah'. The Oregon site had three of the shortest little bluestem records: 'Carousel', 'Jazz', and 'The Blues'. Little bluestem is not native to Oregon (USDA, 2017). It is interesting to compare plant size (Table 5) to origin of these cultivars (Table 1). In this trial, however, cultivars were not necessarily the largest when grown near their origin.

In addition to floral impact, flowering time or months of floral interest were recorded by five locations: 


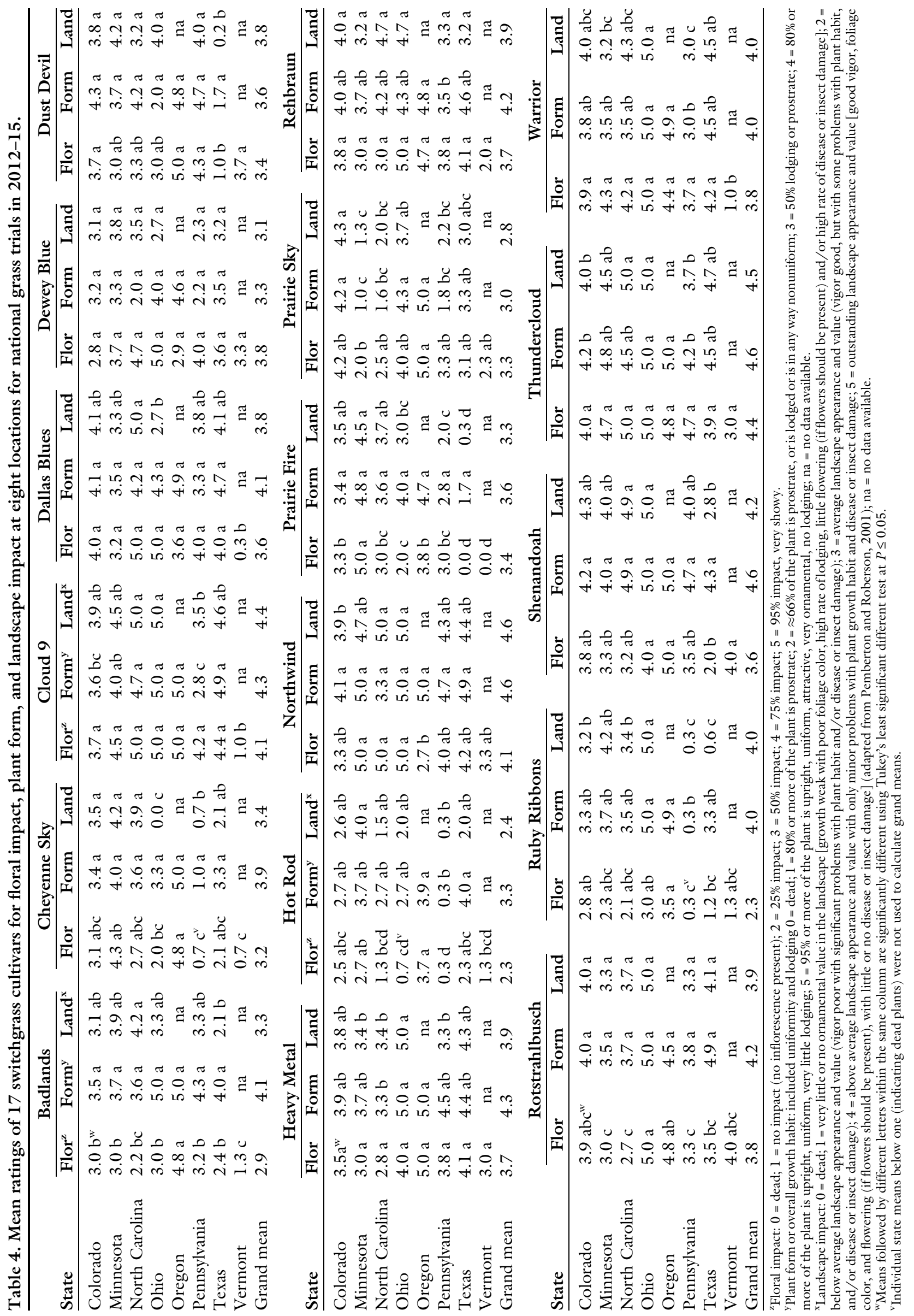


Colorado, Pennsylvania, Minnesota, Ohio, and Oregon and is reported elsewhere (Meyer, 2017). As one would expect, flowering was earliest in southern locations with North Carolina's data showing flowering about one month before Minnesota's data.

Fall color was noted at most locations as yellow, beige, and bronze, etc. North Carolina and Vermont locations used $1-5$ ratings, with 'Blue Heaven' ${ }^{\circledR}$ rating a 5.0 at both locations (data not shown). 'Dallas Blues', 'Northwind', and 'The Blues' also rated a 5.0 for fall color at North Carolina. Oregon recorded fall foliage color using the RHS color chart (RHS, 2007) and other locations reported fall color for 1 year only.

Summer foliage color based on the RHS color chart (RHS, 2007) was recorded by Ohio and Minnesota over 3 years and Pennsylvania for 2013 (data not shown). Other locations reported summer foliage color in descriptive words: blue green, green, and maroon (Meyer, 2017). It was hoped that these trials would ascertain the amount of red summer foliage color especially in newer switchgrass cultivars, however, that did not happen. Not all collaborators were able to purchase the color chart and it proved challenging to match given the 920 colors in the chart.

Five of the eight trial sites reported on pests: Ohio, Oregon, Pennsylvania, Texas, and Minnesota all reported no pests for all cultivars and gave a 5.0 or excellent rating with plants in good health with no visible pest damage.

Participants in Minnesota reported self-seeding as 5.0 (no seedlings) for 'Jazz', and 3.0 (some seedlings) for 'Carousel', 'Blue Heaven ${ }^{\circledR}$, 'Prairie Blues', and 'The Blues'. Texas A\&M Agricultural Research and Extension Center participants reported 4 (very few seedlings) for 'Carousel' selfseeding and 5.0 for all other little bluestem cultivars. Pennsylvania, Ohio, and Oregon locations reported 5.0 for all little bluestem cultivars. In switchgrass, Pennsylvania collaborators rated only 'Cloud Nine' 1.0 with many seedlings near the plant; Minnesota rated only 'Prairie Sky' 1.0; Ohio rated 'Cloud Nine', 'Dallas Blues', 'Dewey Blue' (bitter beachgrass), 'Prairie Sky', and 'Thundercloud' all 1.0 with many seedlings; Texas did not rate any switchgrass as

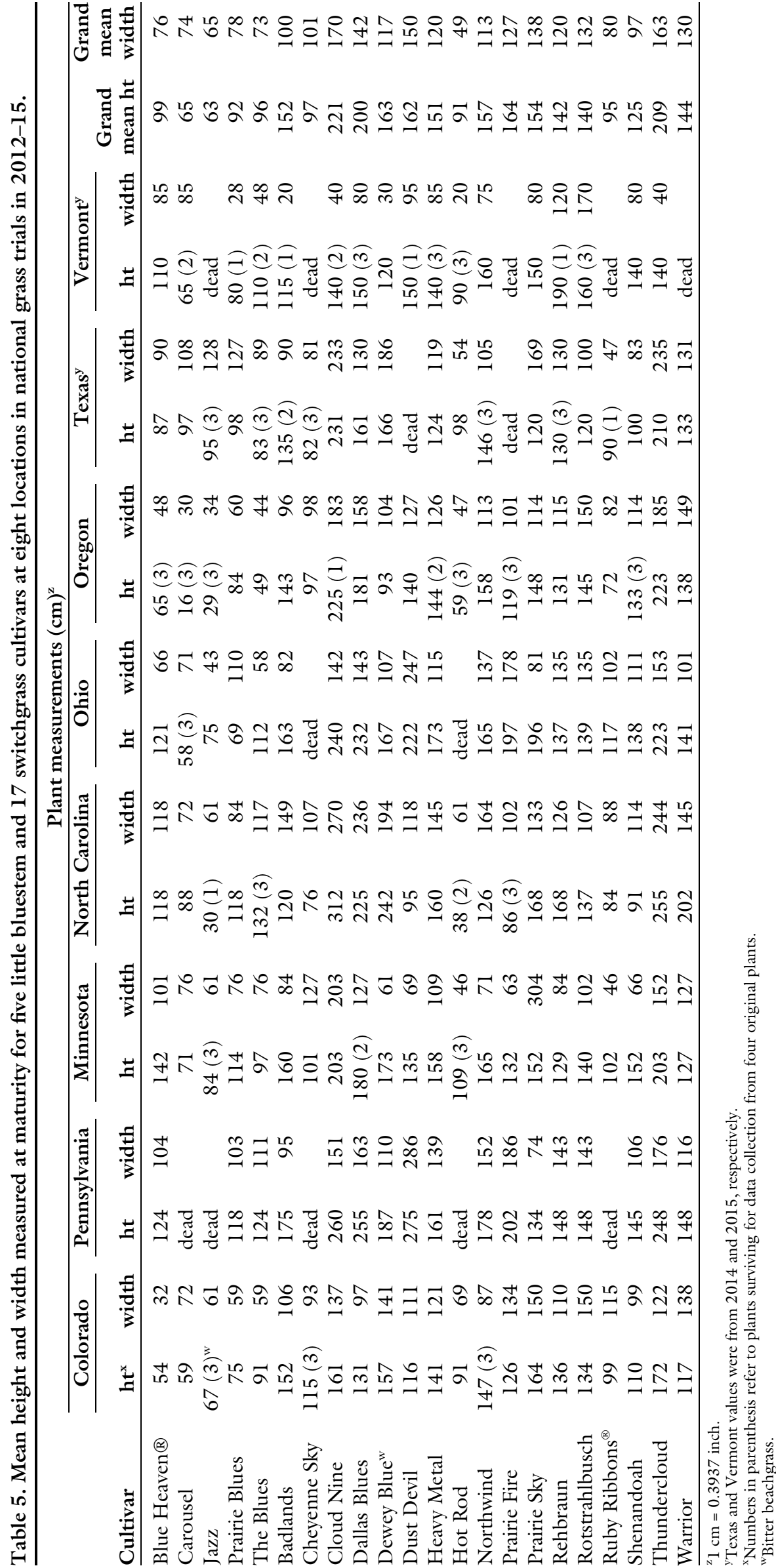


1.0. Pennsylvania participants reported 'Badlands', 'Dallas Blues', 'Dust Devil', 'Heavy Metal', 'Prairie Fire', 'Prairie Sky' 'Rotstrahlbusch', and 'Warrior' as 5.0. Ohio reported 'Badlands', 'Dust Devil', 'Heavy Metal', 'Prairie Fire', 'Rotstrahlbusch', and 'Warrior' as 5.0. Oregon reported only 5.0 ratings for all switchgrass cultivars with no seedlings visible. Texas reported 5.0 for all switchgrass cultivars except 'Dallas Blues' and 'Cloud Nine', which were 3.0. Colorado, North Carolina, and Vermont did not record self-seeding data. Additional switchgrass cultivars were rated 3.0 and can be found online (Meyer, 2017).

Vermont reported the highest winter injury, with all but five cultivars of switchgrass: 'Dewey Blue' (bitter beachgrass), 'Northwind', 'Prairie Sky', 'Shenandoah', and 'Thundercloud', and 'Blue Heaven' ${ }^{\circledR}$ little bluestem showing some death in Vermont. Oregon reported three of four 'Cloud Nine' died from winter injury, two each of 'Heavy Metal', and one each of 'Hot Rod', 'Prairie Fire', 'Shenandoah', 'Blue Heaven' ${ }^{\circledR}$, 'Carousel', and 'Jazz'. Minnesota reported minor winter injury on 'Northwind'; one plant died of 'Jazz'; and $50 \%$ loss (2 of 4 ) for 'Dallas Blues'.

Trial collaborators reported mortality or plant survival not related to winter injury. Florida's four locations had high mortality by 2014 from north to south: $3.9,3.5,2.2$, and 1.4, respectively (where $3=50 \%$ dead). Florida locations could only complete 2 years of this trial (Ripak et al., 2014). Texas participants reported 24 plants or $27 \%$ dead over the 4 years of the project, increasing as the trial continued. Other mortality is reported in Table 5 .

\section{Discussion}

Maintaining perennial plant trials and collecting data over several years is a challenging project to accomplish at multiple locations across the United States. Dedication by collaborators is extremely important, especially their willingness to collect data with little or no financial support. We found wide variation in plant size, form, and landscape impact among locations for the 22 cultivars in this trial. In this report, origin did not predict size or vigor. Historic work of both species (Anderson and Aldous, 1938; McMillan, 1959, 1964) revealed phenotypic variation of ecotypes relating to latitude, daylength, and seasonal temperature variation. Springer (2012) found variation for morphological traits such as canopy morphology, height and width of canopy, and leafiness of the culm. Harris-Shultz et al. (2015) evaluated the same little bluestem cultivars as in our study and found genetic similarity of $86 \%$ based on microsatellite markers, even though selections showed a high degree of morphological variation.

Three of the 17 switchgrass cultivars, Cloud 9, Northwind, and Thundercloud, received final average ratings of 4.0 or higher $(5.0$ scale) for plant form, floral, and landscape impact from trials in a minimum of six states. Only one of the five little bluestem cultivars, Blue Heaven ${ }^{\circledR}$, was rated above average, 4.0 or higher for plant form and landscape impact. Although both species were C4 grasses (plants that have developed an additional pathway to capture carbon dioxide), plants grown in Texas and Florida appeared to have higher mortality, perhaps due to depleted food reserves with increased respiration combined with a shorter or insufficient dormancy.

Results by specific location or state for the highest-ranking cultivars may be the most helpful for consumers, retailers, and growers (Tables 3 and 4). Growers and gardeners need reliable information on plant performance for their region. Although only a few cultivars performed with consistently high ratings across multiple locations in this trial, these results show the importance of regional trials to ascertain plant performance. It is hoped that this work will benefit landscape architects, designers, growers, garden centers, and gardeners in recommending and using these native grasses.

\section{Literature cited}

Adam, S. 2017. Trial garden Pennsylvania State University. 1 Feb. 2017. <http:// trialgardenspsu.com>.

Anderson, K.L. and A.E. Aldous. 1938. Improvement of Andropogon scoparius Michx. by breeding and selection. J. Amer. Soc. Agron. 30:862-869.
Babikow, P. 2015. Panicum virgatum plant named 'Hot Rod'. US PP26074. U.S. Patent Trademark Office, Washington, DC.

Bennett, P. 2017. Ohio State University Extension field trials. 10 Mar. 2017. <http:// clark.osu.edu/program-areas/agricultureand-natural-resources/horticulture/fieldtrials>.

Blazek, D. 2017a. All-America selections. 23 Mar. 2017. <http://all-americaselections. org $>$

Blazek, D. 2017b. Plant trials. 3 Feb. 2017. $<$ http://www.planttrials.org $>$

Boehm, D. 2010. Schizachyrium plant named 'Carousel'. US PP20948. U.S. Patent Trademark Office, Washington, DC.

Brand, M. 2007. Panicum plant named 'RRl'. US PP17944. U.S. Patent Trademark Office, Washington, DC.

Darke, R. 2007. The encyclopedia of grasses for livable landscapes. Timber Press. Portland, OR.

Decker, K. 2017. Dallas Arboretum trial gardens. 3 Feb. 2017. <http://www. dallasplanttrials.org $>$.

Diblik, R. 2017. Northwind Perennial Farms. 17 July 2017. <http:// northwindperennialfarm.com>.

Foerster, K. 1978. Einzug der graser und farne in die garten. Verlag J. NeumannNeudamm. Melsungen, Germany.

Harris-Shultz, K., M. Harrison, P. Wadl, R. Trigiano, and T. Rinehart. 2015. Development and characterization of microsatellite markers for a little bluestem collection. J. Amer. Soc. Hort. Sci. 140:7887.

Hawke, R. 2013. Battle of the grasses. Fine Gardening 154:48-55.

Hawke, R. 2017. Plant evaluation Chicago Botanic Garden. 3 Feb. 2017. <http://www.chicagobotanic.org/ research/ornamental_plant_research/plant_ evaluation>

Hockenberry Meyer, M. 2006. Schizachyrium plant named 'MinnblueA'. US PP17310. U.S. Patent Trademark Office, Washington, DC.

Horvath, B. 2017. Intrinsic perennials. 17 July 2017. <http://www.intrinsicperennialgardens. com>.

Jelitto Perennial Seeds. 2017. Ornamental grasses. 21 Mar. 2017. <https://www. jelitto.com>.

Klett, J.E. 2017. Annual flower trial garden at Colorado State University. 3 Feb. 2017. $<$ http://www.flowertrials.colostate.edus

McMillan, C. 1959. The role of ecotypic variation in the distribution of the central 
VARIETY TRIALS

grassland of North America. Ecol. Monogr. 29:285-307.

McMillan, C. 1964. Ecotypic differentiation within four North American prairie grasses. I. Morphological variation within transplanted community fractions. Amer. J. Bot. 51:1119-1128.

Meyer, M.H. 2012. Ornamental grass in the United States. Hort. Rev. 39:121-152.

Meyer, M.H. 2017. National grass trials. 14 July 2017. <https://grasstrials.com>.

Michigan State University. 2017. Trial gardens at Michigan State University. 1 Feb. 2017. <http://trialgardens.hrt.msu.edu>.

Pemberton, B.H. 2017. Texas superstars. 3 Feb. 2017. <http://www.texassuperstar. com/index.html>.

Pemberton, B.H. and W. Roberson. 2001. The east Texas bedding plant pack and garden performance trials. HortTechnology 11:392-396.

Perennial Resource. 2017a. Panicum virgatum 'Badlands'. 18 July 2017. <http://www.perennialresource.com/ variety.php? ID=PANBA $>$.
Perennial Resource. 2017b. Panicum virgatum 'Dust Devil'. 18 July 2017. <http://www.perennialresource.com/ variety.php?ID=PANDD $>$.

Ripak, N., K. Moore, S. Wilson, Z. Deng, and G. Knox. 2014. Survival of ornamental grasses from north Florida to south Florida. 13 Feb. 2016. <http:// www.sna.org/Resources/Documents/ 14resprosec05.pdf $>$.

Royal Horticultural Society. 2007. RHS large colour chart. 5th ed. 4 Feb. 2017. $<$ ht p://www.rhsshop.co.uk/ productdetails.aspx?id=10000006\& itemno=MARK0011 $>$.

Ruter, J. 2017. Trial gardens at University of Georgia Athens. 3 Feb. 2017. <http:// ugatrial.hort.uga.edu/index.cfm/ fuseaction/home.home/index.htm>.

Smith, L. and K. Smith. 2000. Panicum plant named 'Dallas Blues'. US PP11202. U.S. Patent Trademark Office, Washington, DC.
Springer, T.L. 2012. Variation for canopy morphology in little bluestem. Crop Sci. 52:729-737.

Taylor, M. 2017. Plant trials Longwood Gardens. 3 Feb. 2017. <https://www. longwoodgardens.org/gardens/aboutour-plants/research/plant-trials $>$.

Trucks, G. 2008. Panicum plant named 'Prairie Fire'. US PP19367. U.S. Patent Trademark Office, Washington, DC.

Trucks, G. 2010. Panicum plant named 'Thundercloud'. US PP20665. U.S. Patent Trademark Office, Washington, DC.

Trucks, G. 2012. Panicum plant named 'Cheyenne Sky'. US PP23209. U.S. Patent Trademark Office, Washington, DC.

U.S. Department of Agriculture. 2014. Quick stats. 20 Oct. 2016. <https:// quickstats.nass.usda.gov>.

U.S. Department of Agriculture. 2017. The PLANTS database. 22 Nov. 2016. $<$ http://plants.usda.gov>.

U.S. Patent and Trademark Office. 2017. Patent database. 4 Feb. 2017. <http:// patft.uspto.gov/netahtml/PTO/index. html>. 